EESTI NSV TEADUSTE AKADEEMIA TOIMETISED. V KÖIDE

BIOLOOGILINE SEERIA. 1956, NR. 2

ИЗВЕСТИЯ АКАДЕМИИ НАУК ЭСТОНСКОИ ССР. ТОМ V

СЕРИЯ БИОЛОГИЧЕСКАЯ. 1956, №2 2

\title{
СЕЗОННЫЕ ИЗМЕНЕНИЯ ГУМИНОВЫХ ВЕЩЕСТВ В ВОДЕ БОЛОТНЫХ ОЗЕР ЭСТОНСКОЙ ССР
}

\author{
х. А. Симм, \\ кандидат фармацевтических наук
}

Эстонская ССР богата небольшими озерами, общее число которых превышает 1500. Площадь озер составляет почти 5\% всей территории республики. Характерное для водосборных площадей большинства озер на личие подзолистых почв, обилие лесов, заболоченных земель и верховых болот обусловлено климатом и географическим положением Әстонской ССР. По данным проведенных до сих пор исследований внутренних водоемов вода $1 / 4$ озер ӘССР мало минерализована, имеет кислую реакцию, цветностью от желтой до коричневой и содержит в изобилии органические вещества гумусового происхождения. Таким образом, исследование гумусовых вод в условиях ӘССР имеет существенное значение, тем более, что водный гумус является одной из наименее изученных областей гидрохимии.

С целью изучения сезонных изменений состава гумусовых веществ, содержащихся в воде озер, были выбраны два болотных озера - озеро Парика и Мустъярв, - типичные для территории ЭССР.

Озеро Парика (рис. 1), расположенное среди пространного (верхового, отчасти переходного) болота, является сточным озером. Әто мелкое озеро (средняя глубина 1 м) сильно заросло; образовавшееся низинное болото отделяет озеро от окружающего его верхового болота. По данным съемки (картографирования) 1901 года площадь озера охватывала 150 га; в 1953 году свободная вода его занимала лишь 60 га, причем большая часть дна озера была покрыта подводной растительностью. В результате ежегодного разложения массы вымирающих растений на дне озера накапливается слой подвижного ила толщиной более 5 м.

Озеро Мустъярв (рис. 2) - маленькое глухое озеро площадью всего в 5 га, на водосборных площадях которого расположены заболоченные смешанные леса и болото. Это озеро глубже озера Парика (средняя глубина 3,2 м) и имеет твердое торфяное дно. В противоположность озеру Парика здесь замечается почти полное отсутствие подводной флоры, а грибрежная растительность занимает лишь несколько процентов площади озера.

Параллельно с исследованием вышеуказанных двух типичных для ӘССР болотных озер, проводилось также сезонное изучение гумусовых веществ на третьем болотном озере - озере Кирикумяэ (рис. 3). Озеро Кирикумяэ занимает площадь в 60 га и является мелким сточным озером, на водосборных площадях которого в основном распространяется 
верховое болото, а отчасти песчаный лес. Указанное озеро представляет особый интерес ввиду своей исключительно низкой окисляемости и низкой степени цветности воды, отличаясь тем от всех остальных болотных озер Эстонской ССР.

Надо отметить, что озера Кирикумяэ и Мустъярв питаются круглый год в основном атмосферными осадками, в то время как озеро Парика, обладающее донными (грунтовыми) источниками, питается также грунтовыми водами.

Из всех указанных озер были взяты для анализа пробы воды 4 раза в год: в летнее и зимнее мелководье, в осенний дождливый период и в весеннее полноводье. При определении органических веществ в воде был применен фракционированный метод анализа П. П. Воронкова и О. К. Со . коловой $(1950) *$. Из содержащихся в воде органических веществ были выделены 3 фракции: фракция гуминовых кислот, фракция фульвокислот и фракция истинно растворенных органических веществ. В воде и в каждой фракции в отдельности были определены общая цветность, перманганатная и бихроматная окисляемость.
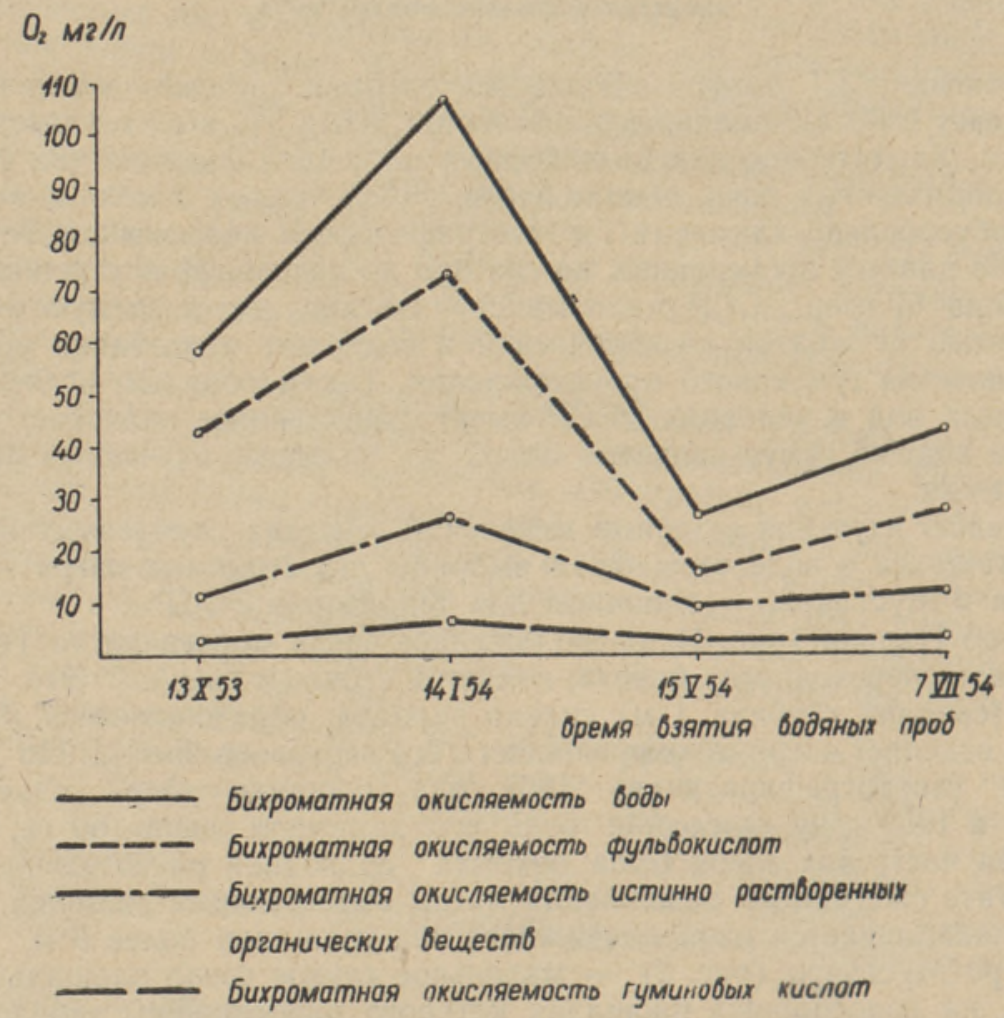

Рис. 1. Сезонные изменения содержания органического вещества и их отдельных фракций в воде озера Парика.

О содержании органических веществ в воде озера Парика можно судить по рис. 4. По этому рисунку видно, что содержание органических веществ в воде озера в течение года сильно колеблется: бихроматная окисляемость повышается с 27,6 $\mathrm{O}_{2}$ мг/л до $110,8 \mathrm{O}_{2}$ мг/л.

* П. П. Воронков и О. К. Соколов а, Гумусовые вещества поверхностных вод Карельского перешейка, Труды Государственного гидрологического института, вып. 25 (79), 1950. 


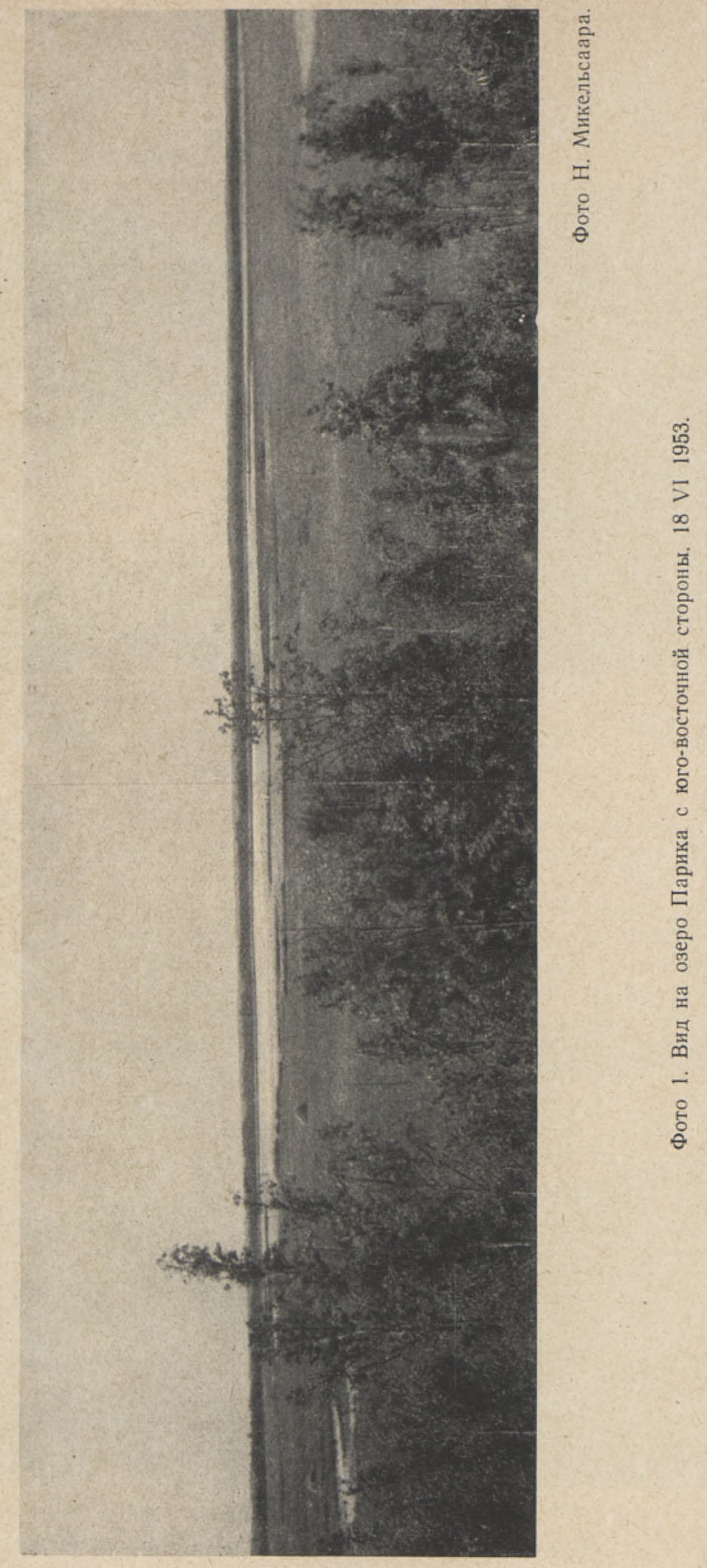




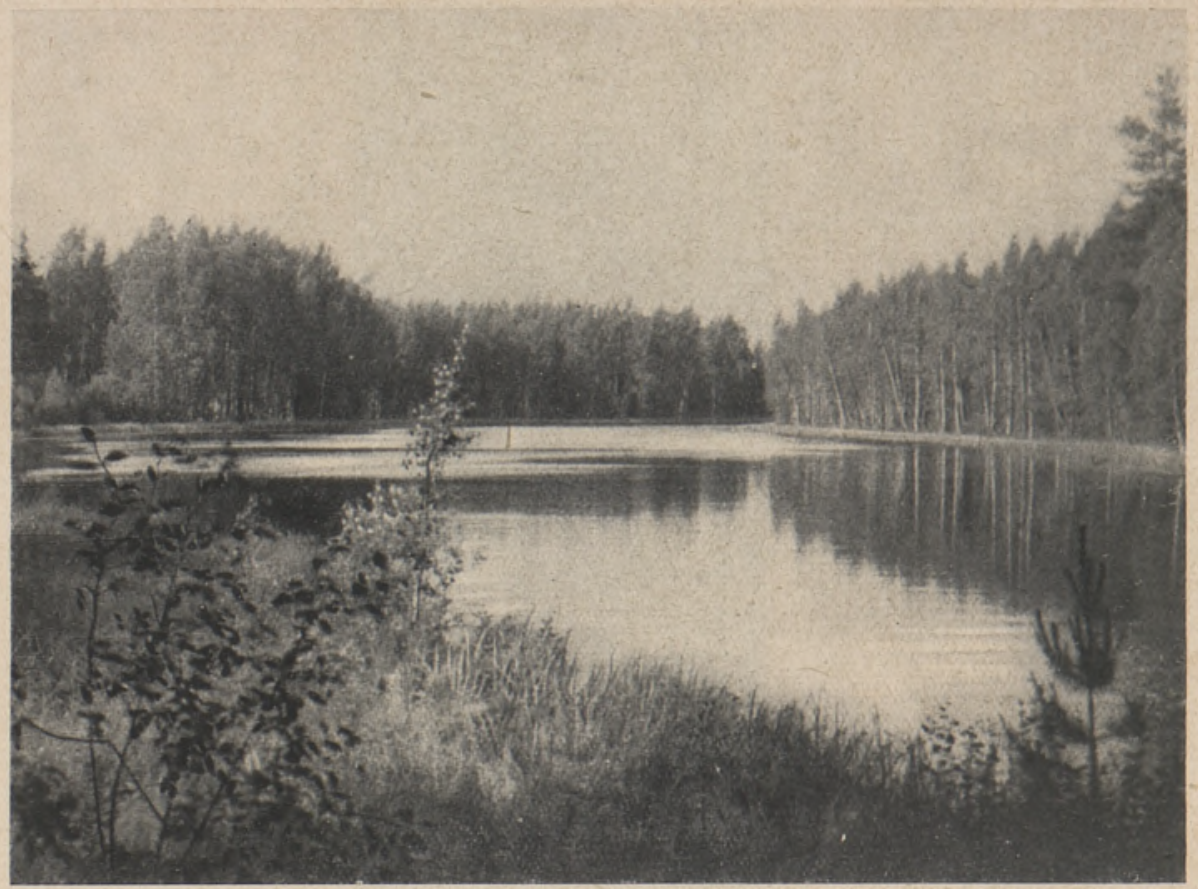

Фото Н. Микельсаара.

Фото 2. Вид на озеро Мустъярв с южкой стороны, 29 VII 1953.

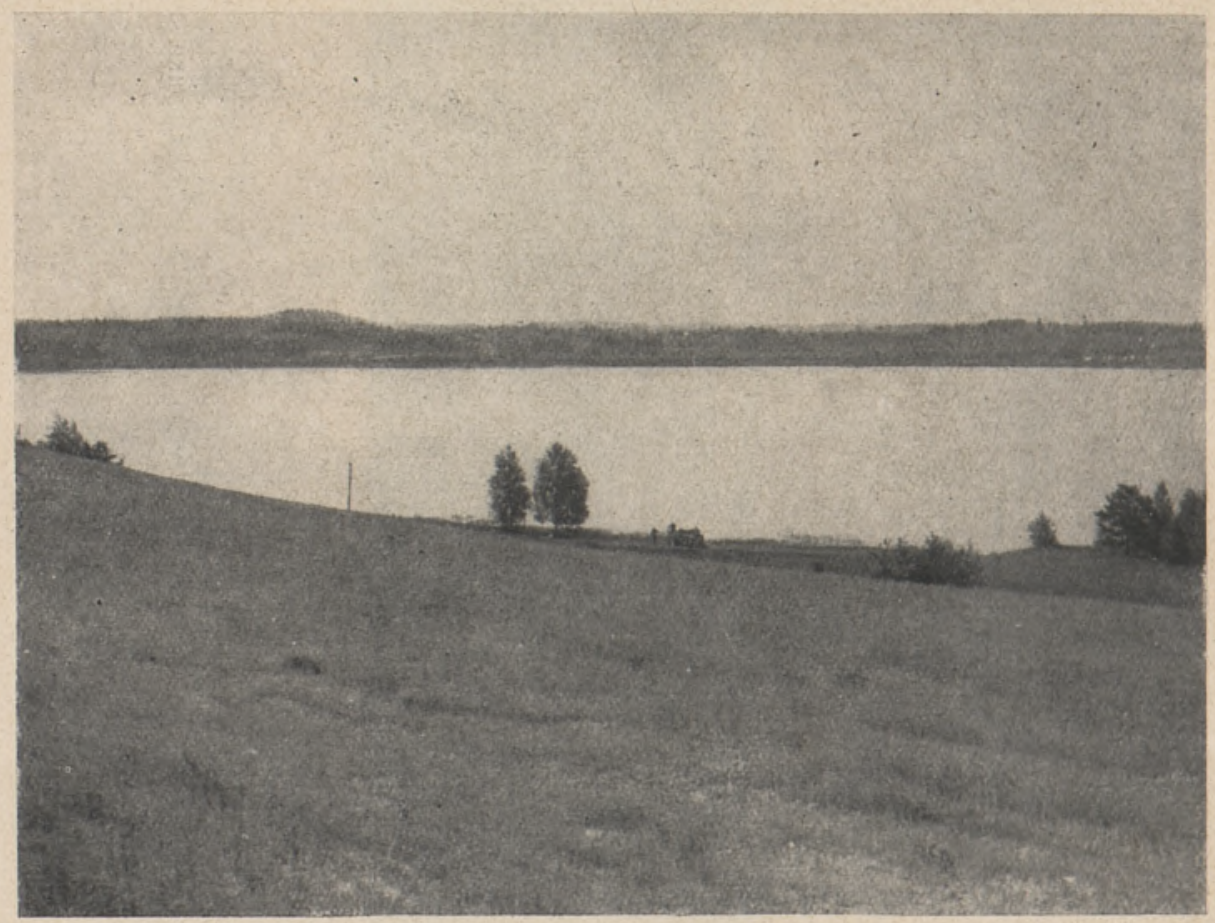

Фото Н. Микельсаара.

Фото 3. Вид на озеро Кирикумяэ с северной стороны. 22 VI 1952. 
Осенняя высокая бихроматная окисляемость воды $\left(60,8 \mathrm{O}_{2} \mathrm{Mr} / л\right)$ явно обусловлена принесенными из окружающих болот органическими веществами, а также разложением обильно накопленного в озере отжившего растительного материала и его растворением в воде. Продолжающееся разложение растительных остатков и отсутствие разбавляющего действия атмосферных осадков еще более повышают бихроматную окисляемость воды, достигающую к зимнему мелководью годового максимума $\left(110,8 \mathrm{O}_{2} \mathrm{Mг} / \pi\right)$.

В результате разложения растительных остатков и ввиду того, что озеро зимой питается бедными кислородом и богатыми железом грунтовыми водами, количество растворенного в воде кислорода непрерывно уменьшается (в январе всего лишь 4\% от насыщенности), что к концу зимы создает в озере благоприятные условия для высаждения гумусовых веществ. Очевидно, в основном выпадают фульвокислоты вместе с соединениями железа, так как параллельно с зимним понижением бихроматной окисляемости воды с $110,8 \mathrm{O}_{2}$ мг/л до $27,6 \mathrm{O}_{2}$ мг/л, к весне понижается и содержание железа $\left(\mathrm{Fe}^{*}+\mathrm{F}^{*}\right)$ с $1,5 \mathrm{mr} / \pi$ до $0,08 \mathrm{мг} / л$, а процент содержания фульвокислот в органических веществах воды снижается с 69 до 58.

Вследствие высаждения растворенных в воде органических веществ и под влиянием талых вод содержание органических веществ в воде снижается весной до минимума. К периоду летнего мелководья бихроматная окисляемость воды повышается до 44,3 мг/л.

В составе органических веществ в воде озера Парика в течение всего года преобладают фульвокислоты $(58-74 \%)$, гуминовые кислоты встречаются в наименьшем количестве $(5-9 \%)$. При этом замечается, что процент бихроматной окисляемости отдельных фракций по отношению к общей бихроматной окисляемости воды изменяется посезонно. Относительное содержание фульвокислот в воде осенью значительно повышается и соответственно уменьшается значение истинно растворенных органических веществ. Весной же, в результате выпадения фульвокислот, наблюдается противоположная картина.

Содержание гуминовых кислот мало изменяется в течение года.

Цветность воды изменяется в общих чертах параллельно изменениям бихроматной окисляемости $\left(87^{\circ}-500^{\circ}\right)$. При этом интересно отметить, что коэффициент цветности воды (а также фракции фульвокислот) к бихроматной окисляемости * в осенний и зимний периоды значительно больше, чем в весенний и летний периоды $(4,2-4,5$ и $3,1-3,2)$. То же происходит и с процентом перманганатной окисляемости воды ** (также фульвокислот) - осенью и зимой этот процент выше, чем весной и летом. Из вышесказанного следует, что в конце зимы из воды преимущественно выпадают темноцветные и с более высокой окисляемостью органические вещества (т. е. фульвокислоты).

По данным, приведенным на рис. 5, касающимся бихроматной окисляемости воды в озере Мустъярв, видно, что содержание органических веществ в воде этого глухого озера мало подвергается сезонным изменениям, бихроматная окисляемость воды колеблется между 54,6-68,0

* T. е. отношение $\frac{\text { цветность }}{\text { бихроматная окисляемость } \mathrm{O}_{2} \mathrm{mr} / \mathrm{л}}$ воды или фракция. По литературным данным названный коэффициент зависит от характера и состава органических веществ.

** $\mathrm{T}$ е. отношение $\frac{\text { перманганатная окисляемость } \mathrm{O}_{2} \mathrm{mr} / \mathrm{r}}{\text { бихроматная окисляемость } \mathrm{O}_{2} \mathrm{Mr} / \mathrm{\pi}} \cdot 100$, которое показывал соотношение между легко и трудно окисляемыми органическими веществами воды, характеризует степень трансформации органических веществ.

4 Tead. Akad. Toimetised. B2-56 
$\mathrm{O}_{2}$ мг/л. Так как озеро питается исключительно атмосферными осадками, содержание органических веществ в его воде является наименьшим осенью, в период дождей, и наибольшим зимой. Зимнее содержание органических веществ в озере $\mathrm{k}$ весне несколько падает (с $68,0 \mathrm{O}_{2}$ мг/л до $64,4 \mathrm{O}_{2}$ мг/л), в чем сказывается влияние талых вод (вследствие малоснежной зимы 1954 года типичного полноводья не замечалось), и удерживается в прохладное и дождливое лето почти в тех же пределах.
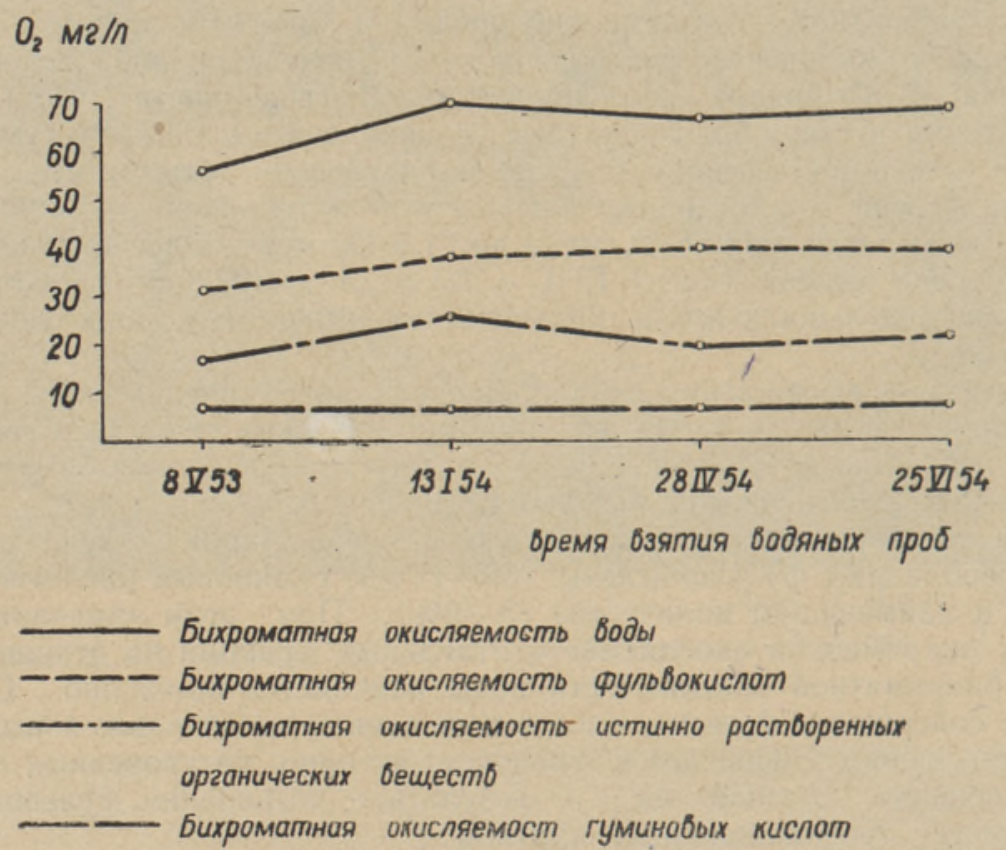

Рис. 2. Сезонные изменения содержания органического вещества и их отдельных фракций в воде озера Мустъярв.

В составе органических веществ в воде озера Мустъярв, аналогично озеру Парика, первенствует фракция фульвокислот (53-60\% общей окисляемости воды), причем фракция гуминовых кислот находится на последнем месте (10-13\% общей окисляемости воды). Взаимоотношения между отдельными фракциями органических веществ в воде в течение года почти не изменяются, не считая зимнего периода, когда вследствие более интенсивно проходящей трансформации органических веществ в самом озере несколько изменяется отношение между фульвокислотами и истинно растворенными органическими веществами.

Цветность воды изменяется параллельно содержанию органических веществ $\left(217^{\circ}-280^{\circ}\right)$. Коэффициент цветности воды к бихроматной окисляемости стабилен в течение всего года $(4,0-4,1)$.

Сезонное колебание содержания органических веществ в воде озера Кирикумяэ еще меньше, чем в воде Мустъярв (рис. 6). Содержание органических веществ в воде этого озера, питаемого в основном атмосферными осадками, самое низкое осенью $\left(16,4 \mathrm{O}_{2}\right.$ мг/л) и самое высокое зимой $\left(24,8 \mathrm{O}_{2} \mathrm{Mr} / \pi\right)$.

Состав органических веществ в воде озера Кирикумяэ отличается от состава органического вещества в воде вышеописанных озер преоблада- 
нием фракции истинно растворенных органических веществ. Бихроматная окисляемость фракции истинно растворенных органических веществ составляет в течение всего года $49-52 \%$ от всей бихроматной окисляемости воды озеро Кирикумяэ; окисляемость фракции фульвокислот 39$43 \%$ и окисляемость гуминовых кислот $7-10 \%$.

Высшая степень цветности фракции истинно растворенных органических веществ в воде озера Кирикумяэ (9-10\% от общей цветности воды) по сравнению с другими озерами (большей частью $3-5 \%$ от общей цветности) позволяет предполагать, что указанная фракция увеличивается за счет накопления фульвокислот не коагулирующих с $\mathrm{Al}_{2}\left(\mathrm{SO}_{4}\right)_{3}$.
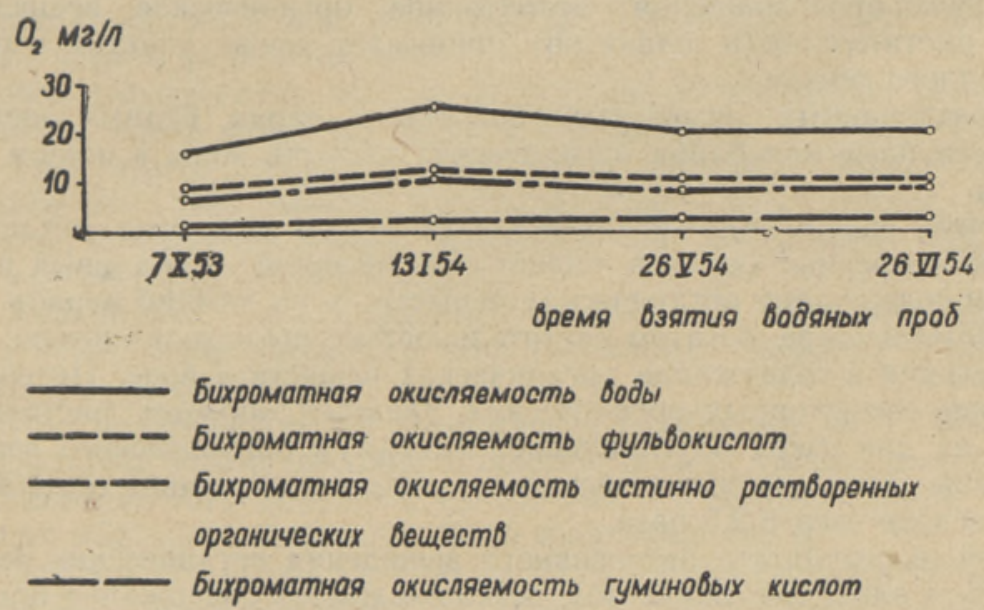

Рис. 3. Сезонные изменения содержания органического вещества и их отдельных фракций в воде озера Кирикумяэ.

За исключением весеннего периода, когда отношения отдельных фракций в результате падения фульвокислот и комплекса соединений железа несколько изменяются, это отношение в течение всего года весьма постоянно (гуминовых кислот $7-8 \%$, фульвокислот $42-43 \%$ и истинно растворенных органических веществ 49-50\%).

Аналогично озеру Парика, процент перманганатной окисляемости воды (т. е. фульвокислот) озера Кирикумяэ и коэффициент цветности воды к бихроматной окисляемости в весенний и летний периоды ниже, чем в осенний и зимний перноды.

Степень цветности воды в озере Кирикумяэ $\left(39^{\circ}-68^{\circ}\right)$ в общем низкая (коэффициент цветности воды к бихроматной окисляемости составляет $2,0-2,8)$, что обусловлено, преобладанием в содержании органических веществ воды малоцветной фракции истинно растворенных органических веществ.

Почему вода в озере Кирикумяэ отличается от других болотных озер значительно меньшей бихроматной окисляемостью - вопрос еще не разрешенный.

О происходящих в воде озера интенсивных процессах трансформации органических веществ свидетельствует наблюдаемое в воде сильное сезонное колебание процента перманганатной окисляемости органического вещества воды (а также отдельных фракций).

Подытоживая результаты проведенного исследования, можно сказать следующее: 
1. Наибольшую часть органических веществ в воде болотных озер Әстонии составляет фракция фульвокислот, меньшую часть - фракция гуминовых кислот.

Иной характер имеет озеро Кирикумяэ, где в составе органических веществ преобладает фракция истинно растворенных органических веществ.

Высшая степень цветности названной фракции в воде озера Кирикумяэ позволяет утверждать, что фракция истинно растворенных органических веществ увеличивается за счет фульвокислот, не осаждаемых посредством $\mathrm{Al}_{2}\left(\mathrm{SO}_{4}\right)_{3}$.

2. Гуминовые вещества воды болотных озер являются в основном аллохтонного происхождения, автохтонное органическое вещество же (водная растительность, планктон) принимает также участие в образовании водного гумуса.

В исследованных замкнутых болотных озерах, бедных растительностью, сезонные колебания органических веществ воды в общем незначительны.

Минимум содержания органических веществ в воде озер, питающихся за счет атмосферных осадков, піадает на осенний дождливый период; максимум содержания органических веществ - на зимний период.

В болотном озере, богатом растительностью, происходят резкие сезонные изменения в содержании органических веществ в воде. Интенсивное разложение автохтонных органических, главным образом, растительных остатков на дне озера обусловливает максимум органического вещества воды зимой. Этот максимум превышает летнее содержание органических веществ в воде озер в 2,5 раза.

Весной, в результате интенсивного выпадения органичесқих веществ, а также под влиянием талых вод, резко снижается содержание органических веществ в воде, составляя лишь $1 / 4$ зимнего количества органических веществ воды (весенний минимум).

3. Отношение между содержанием отдельных фракций органического вещества меняется в течение года в основном за счет скопления и выпадения фракции фульвокислот.

Скопившиеся в воде в осенние и зимние периоды фульвокислоты отличаются от фульвокислот, находящихся в воде озер весной и летом, высокой степенью цветности и перманганатной окисляемости.

Вышесказанное указывает на то, что из фракции фульвокислот в конце зимы выпадают преимущественно темноцветные и обладающие высокой перманганатной окисляемостью фульвокислоты, как наименее трансформированная и наиболее лабильная часть водного органического вещества.

4. Сезонные изменения степени перманганатной окисляемости и цветности одной и той же фракции водного органического вещества одного и того же озера доказывают, что в озерах происходят интенсивные процессы трансформации органических веществ.

Ход этих процессов отражает как отношение между озером и его водосборной площадью, так и особенности химизма воды озера.

Ннститут зоологии и ботаники

Академии наук Эстонской ССР
Поступила в редакцию

$28 \times 1955$ 


\title{
HUUMUSAINETE SESOONSED MUUTUSED EESTI NSV RABAJÄRVEDE VEES
}

\author{
H. SIMM,
}

farmaatsiateaduste kandidaat

\section{Resümee}

1. Uuritud rabajärvede vete orgaanilisest ainest moodustab kogu aasta vältel suurema osa fulvohapete fraktsioon, väiksema osa humiinhapete fraktsioon. Järvede vees lahustunud orgaaniliste ainete fraktsioonide sisalduse suhe vastab soostunud alade pinnase orgaaniliste ainete fraktsioonide sisalduse suhtele ja lahustuvusele.

Teistest rabajärvedest erineva iseloomuga on Kirikumäe järv, kus vee orgaaniliste ainete koostises on pidevalt ülekaalus tõeliselt lahustunud orgaaniliste ainete fraktsioon. Nimetatud fraktsiooni kõrgem värvusaste Kirikumäe järve vees (võrreldes teiste järvedega) laseb oletada, et tõeliselt lahustunud orgaaniliste ainete fraktsioon on suurenenud $\mathrm{Al}_{2}\left(\mathrm{SO}_{4}\right)_{3}$-ga mittekoaguleeruvate fulvohapete arvel.

2. Rabajärvede vee huumusained on põhiliselt allohtoonse päritoluga, kuid ka autohtoonne orgaaniline laine (veetaimed, plankton) võtab osa vee huumuse moodustumisest.

Uuritud taimestikuvaestes rabajärvedes (Kirikumäe järv, Mustjärv) on vee orgaaniliste lainete sesoonne kõikumine üldiselt väikese ulatusega. Toitudes atmosfäärseist sademeist, esineb vee orgaaniliste ainete sisalduse miinimum sügisesel vihmaperioodil ja maksimum talvel.

Taimestikurikka rabajärve (Parika järv) vee orgaaniliste ainete sisalduses toimuvad järsud sesoonsed muutused. Järve kogunenud autohtoonsete orgaaniliste jäätmete (surnud veetaimede) intensiivne lagunemine põhjustab talvel vee orgaaniliste ainete sisalduse maksimumi, mis hulgaliselt ületab suvise vee orgaaniliste ainete sisalduse 2,5-kordselt. Taimsete jäätmete lagunemise ja järve talvise toitumise tõttu hapnikuvaestest ja rauarikastest pöhjavetest kujunevad järves talve lõpuks välja tingimused, mis on soodsad huumusainete sadenemiseks koos rauaühenditega. Intensiivse orgaaniliste lainete sadenemise ja sulavete mõjul langeb vee orgaaniliste ainete sisaldus kevadeks järsult, moodustades ainult 1/4 talvisest vee orgaaniliste, ainete sisaldusest (kevadine miinimum).

3. Järvede vee orgaaniliste ainete üksikute fraktsioonide sisalduse suhted muutuvad aasta vältel põhiliselt fulvohapete fraktsiooni kogunemise ja sadenemise arvel.

Sügisesel ja talvisel perioodil järve vette kogunenud fulvohapped erinevad järve vee kevadistest ja suvistest fulvohapetest kõrgema värvusastme ja koorgema permanganaatse hapendumuse astme poolest. Eelöeldu näitab, et fulvohapete fraktsioonist sadenevad talve lõpul välja peamiselt tumedavärvuselised ja kõrge permanganaatse hapendumusega fulvohapped kui kōige vähem transformeerunud ja ebastabiilseim osa vee orgaanilistest ainetest.

4. Uhe ja sama järve vee orgaanilise aine ühe ja sama fraktsiooni permanganaatse hapendumuse ja värvuse astme sesoonne kõikumine näitab, et järves toimuvad intensiivsed orgaaniliste ainete transformeerumise protsessid.

Nende protsesside kulgemine peegeldab nii järve ja selle valg-ala suhte kui ka järve enda veekemismi tüüpilist omapära. 


\section{DIE JAHRESZEITLICH BEDINGTEN ÄNDERUNGEN DER HUMUS- STOFFE IM WASSER DER MOORSEEN DER ESTNISCHEN SSR}

\section{H. SIMM}

\section{Zusammenfassung}

Die Ergebnisse der bisher vorgenommenen Untersuchungen der jahreszeitlich bedingten Dynamik der Humusbestandteile des Wassers in den für die Estnische SSR typischen Moorseen gestatten nachstehende Schlussfolgerungen:

1. Der organische Stoff des untersuchten Wassers der Moorseen wird im Laufe des ganzen Jahres aus einer grösseren Fraktion von Fulvosäuren und einem geringeren Teil von Huminsäuren gebildet. Das Verhältnis der Zusammensetzung der Fraktionen der im Moorseenwasser aufgelösten organischen Stoffe entspricht dem Verhältnis und der Löslichkeit des Gehalts der Fraktionen der im Boden versumpfter Gelände enthaltenen organischen Stoffe.

Einen von den übrigen Moorseen abweichenden Charakter weist der Kirikumäe-See auf, wo in der Zusammensetzung der organischen Stoffe des Wassers ständig die Fraktion der vollständig laufgelösten organischen Stoffe dominiert. Die intensivere Färbung der erwähnten Fraktion im Wasserbestland des Kirikumäe-Sees (verglichen mit anderen Moorseen) legt die Vermutung nahe, dass die Fraktion der vollständig aufgelösten organischen Stoffe angewachsen ist auf Rechnung der mit $\mathrm{Al}_{2}\left(\mathrm{SO}_{4}\right)_{3}$ nicht koagulierenden Fulvosäuren.

2. Die Humusstoffe des Wassers in den Moorseen sind vorwiegend allochthonen Ursprungs, doch haben auch autochthone organische Stoffe (Wasserpflanzen, Plankton) Anteil an der Bildung des Humus.

In den pflanzenarmen Moorseen (der Kirikumäe-See, der Mustjärv) ist der Umfang der jahreszeitlich bedingten Schwankungen der im Wasser enthaltenen organischen Stoffe nur gering. Da sie ihre Nahrung aus den atmosphärischen Niederschlägen schöpfen, weisen die Wlasser dieser Seen ihrer Minimalgehalt an organischen Stoffen während der herbstlichen Regenperiode auf, das Maximum dagegen in den Wintermonaten.

In einem pflanzenreichen Moorsee (der Parika-See) konnten dagegen, anhängig von der Jahreszeit, starke Schwankungen im Bestande der organischen Stoffe des Wlassers beobachtet werden. Die intensive Zersetzung der im See aufgespeicherten autochthonen organischen Rückstände (abgestorbene Wasserpflanzen) führt während des Winters zum maximalen Gehalt an organischen Stoffen im Wasser, welcher den sommerlichen Bestand der organischen Stoffes des Wassers um 2,5-mal übersteigt. Infolge der Zersetzung von pflanzlichen Rückständen und der aus den säurearmen und eisenreichen Grundwassern stammenden Winternahrung des Sees, entwickeln sich zu Ende des Winters Bedingungen, welche die Ausscheidung von Humusstoffen mit Eisenverbindungen begünstigen. Im Ergebnis der intensiven Ausscheidung von organischen Stoffen und unter der Einwirkung der Schmelzwasser sinkt im Frühjahr der Bestand an organischen Stoffen des Wassers sehr stark - erreicht bloss 1/4 des winterlichen Gehalts an organischen Stoffen im Wasser des Sees (Frühjlahrsminimum).

3. Der Anteil der einzelnen Fraktionen lan der Zusammensetzung der organischen Stoffe des Moorseenwassers ändert sich im Laufe des Jahres* hauptsächlich im Zusammenhang mit der Aufspeicherung bezw. der Ausscheidung der Fulvosäurenfraktion.

Die im Laufe der Herbst- und Winterperiode im Moorseenwasser aufgespeicherten Fulvosäuren unterscheiden sich von der frühjährlichen und 
sommerlichen Fulvosäuren durch eine intensivere Färbung und eine höhere Stufe der Permanganatoxydation. Aus dem Vorhergesagten ergibt sich, dass die Fulvosäurenfraktion zu Ende des Winters vorwiegend Fulvosäuren von dunkler Färbung und hoher Permanganatoxydation ausscheidet - als die am geringsten transformierten und am wenigsten stabilen Bestandteile der organischen Stoffe des Moorseenwassers.

4. Die jahreszeitlichen Schwankungen in der Intensität der Färbung und der Stufe der Permanganatoxydation innerhalb ein- und derselben Fraktion des organischen Stoffes des ein- und demselben Moorsee entnommenen Wassers zeigen, dass im See intensive Prozesse der Transformierung der organischen Stoffe vorsichgehen.

Der Verlauf dieser Prozesse widerspiegelt wie das Verhältnis zwischen dem See und seinem Einzugsgebiete, so auch die typische Eigenart des Chemismus des Seewassers. 